This item was submitted to Loughborough's Research Repository by the author.

Items in Figshare are protected by copyright, with all rights reserved, unless otherwise indicated.

\title{
Theoretical and methodological considerations for the study of banal and everyday nationalism
}

\section{PLEASE CITE THE PUBLISHED VERSION}

https://doi.org/10.1111/nana.12419

\section{PUBLISHER}

(c) The author(s) 2018. Nations and Nationalism @ ASEN/John Wiley \& Sons Ltd 2018

\section{VERSION}

AM (Accepted Manuscript)

\section{PUBLISHER STATEMENT}

This is the peer reviewed version of the following article: HEARN, J. and ANTONSICH, M., 2018. Theoretical and methodological considerations for the study of banal and everyday nationalism. Nations and Nationalism, 24(3), pp. 594-605, which has been published in final form at https://doi.org/10.1111/nana.12419. This article may be used for non-commercial purposes in accordance with Wiley Terms and Conditions for Use of SelfArchived Versions.

\section{LICENCE}

CC BY-NC-ND 4.0

\section{REPOSITORY RECORD}

Hearn, Jonathan, and Marco Antonsich. 2018. "Theoretical and Methodological Considerations for the Study of Banal and Everyday Nationalism”. figshare. https://hdl.handle.net/2134/32380. 
Forthcoming in Nations and Nationalism, 2018

Theoretical and methodological considerations for the study of banal and everyday nationalism

Jonathan Hearn and Marco Antonsich

\section{Introduction}

This themed section grapples with the problem of how we find evidence for 'everyday nationalism'. As the range of work in this area has blossomed in recent years, it is a timely intervention. In their introduction Fox and Ginderachter begin to lay out the problem through a couple of distinctions. First they distinguish between macro and micro approaches to the study of nationalism, locating their problem at the micro end. They suggest that 'macro-structural' or 'macro-historical' approaches have focused on questions of the historical origins and formation of modern nationalism, the role of states and their various institutions, and encompassing political economic processes. The everyday focus is seen as a micro counterpoint to this, looking at how nations and nationalism are made from the bottom up rather than the top down. They also distinguish between 'banal nationalism', as articulated influentially by Michael Billig (1995), and 'everyday nationalism'. They locate both these foci at the more micro end, but suggest that banal nationalism is more concerned with the implicit, largely subliminal discursive forms that nationalism takes, that can be observed and brought to light by researchers. In contrast, everyday nationalism focuses more on the 'practical accomplishment of ordinary people doing ordinary things'. It is about human agency, no matter how small and casual. People call forth these national categories, find them meaningful, and act in terms of them in certain situations.

In this concluding article, we would like to reflect on the endeavour of searching for evidence of the 'unseen', 'unheard', and 'unnoticed' of the nation. While we are genuinely sympathetic to this research agenda, we also would like to advance some theoretical and methodological considerations which we believe might help refine this endeavour. We start by pointing to the necessity of bridging macro and micro approaches to the study of nationalism. We reflect on this issue by looking more specifically at the notion of individual agency, which is the characterising feature of the everyday approach to the nation. We argue that emphasising the centrality of individual agency would not lead to a deeper understanding of nationalism unless it is studied in relation to the social organisational context within which individual practices take place. This point is also carried forward in our scrutiny of how everyday nationalism approaches questions of 'meaning' and 'identity'. Any attempt at addressing the 'evidence problem' should in fact be clear about the rationale for collecting that evidence, because if meanings orient social actions then again a focus on the micro cannot be sufficient to explain the thrust of the nation in shaping social life. Similarly, (national) identity should be studied in its individual and social components. 
Therefore, everyday nationalism's focus on the individual should once again not be detached from the social organisational contexts (e.g. families, workplaces, educational spaces, etc.) which mediate more structural (macro) dimensions of the nation. An additional question is also related to the notion of 'legitimacy'. In fact, while banal nationalism clearly works for legitimising the idea of the nation-state in the eyes of its members, it is not as clear how everyday nationalism stands in relation to the same question. Finally, we reflect on the implicit assumption which largely operates within both banal and everyday nationalism, namely the idea of a nation defined in the singular. We argue instead for a research programme which explores how the everyday brings to the fore a plurality of understandings of nation, thus opening up a category traditionally depicted in mono- cultural tones.

\section{Individual agency between the micro and macro of the nation}

The first question we might ask is: how micro is banal nationalism? While certainly there was no large historical or political economic thesis in Billig's book, the patterns of discourse and habitus he was directing attention to are very large. They are discursive structures within which people act, even while being mostly unaware of those structures. This was the point, that because the national discourse is so multiform and pervasive, it is well entrenched and ready to be mobilised when politics heats up. The banal can become 'hot' (see Christian, Dowler, \& Cuomo, 2015; Jones \& Merriman, 2009). We should be wary of a taken-for-granted association of the discursive with the micro. While every actual moment of 'meaningfulness' may have to take place in some individual's head, or an interacting group of individuals' heads, nonetheless we can study banal national discourses as macro-phenomena, evidenced in extensive rhetorical patterns that the researcher has learned to read, without direct recourse to the minds and meaning-making of actual actors. It may be that this claim is less true of everyday nationalism, and that is part of the distinction being made here. Everyday nationalism may be defined by the aim to study the acts of meaning-making, and how they work, rather than the large patterns they instantiate.

This directs us closer to the classic question of agency. If nations and nationalism are human creations, then surely its ultimate origins lie in those on going acts of instantiation that make them real from day to day. This would seem to be the basic idea that underlies the everyday approach defined here. And, it is an assumption, or at least bias, basic to various forms of micro-sociological analysis: phenomenological, ethnomethodological, symbolic interactionist, and so on. Pursuing this point requires us to think more carefully about what we mean by agency.

In recent years there has been a tendency in some quarters to reduce agency to action, delinking it from questions of will and intention. In formulating his theory of structuration Anthony Giddens (Giddens, 1984) tended to treat agency as any kind of human action, regardless of intention. Actor-Network theorists such as Bruno Latour (Latour, 1987) have argued against treating agency as specifically human, extending the role of 'actor' to machines, animals, even mathematical formulae-anything that does something that enters into a causal nexus. Indeed the difference between agency and causation tends to dissolve in this approach. The everyday approach to nationalism doesn't seem to go to this extreme. 
But that means it does have to deal with questions of will and intention in agency, and that's where it gets difficult. To take a standard example, sticking with human action in this context, if people do not speak a language on a daily basis, it tends to die out. The action of speaking carried on by myriad individuals sustains the language, keeps it going and evolving. But this is rarely the intention of the speakers, who are just going about their normal business. They speak with intentions, but the intentions are to get other things done, not to support the language they are using itself. The latter is a side effect.

Fox and Ginderachter note the 'now-you-see-it, now-you don't' aspect of everyday nationalism. It becomes visible when it is a salient frame of action, or something in regard to which people deliberately act in various small ways, but it is always prone to sink back below consciousness, to become more 'banal' again. This way of conceiving the object of study would seem to have a lot in common with the example of language. Sometimes people treat their language as the object of their actions (e.g. using 's/he'), sometimes they are consciously using it to achieve some extra-linguistic end ('that's an order!'), and most of the time they pursue their ends unconsciously relying on the taken-for-granted medium of language. Similarly there are distinctions to be teased apart, between when nationalism enters into everyday consciousness as an object of intention and action, however fleetingly, when it frames actions as a consciously invoked category but is not itself the point of the action, and when it operates as an implicit, invisible background assumption. For instance, consider the differences between: an American going out of their way to indicate their awareness of politics around the globe to counter stereotypes of American parochialism; knowing which line to get into to pass customs when entering a country; and seeking professional accreditation according to national regulating bodies, or seeking a national tax rebate. Each of these modes of acting in national terms implies different kinds of evidence. More fundamentally, they may deserve different kinds of weight in a theoretical account of how nationalism is grounded in everyday action.

There is another issue here. Discussions of agency often proceed with an assumed paradigm of the individual agent, and a micro focus will tend to converge with this assumption. However, much of the human agency that matters in this world is carried out not by individuals, but various kinds of groups and organisations (for instance states and political parties obviously, but all kinds of civil society formations as well). While these larger agents may aggregate the wills and intentions of individuals, the wholes are inevitably greater than the sum of their parts (Kaufmann, 2017). Nationalism as social action may be in key respects an emergent property of complexly organised behaviour that cannot be disaggregated to more micro levels of analysis. The bedrock of individual agency, and social settings of direct interaction among individuals, while they may reveal specific aspects of how people connect to nationalism, may not be adequate to explain everyday nationalism in general precisely because it is a product of its social organisational context in the first place.

To illustrate this point, Hearn (2017) found, in his ethnographic study of the merger of the Bank of Scotland and the Halifax to form HBOS, that perceived differences in national character were sometimes invoked to help explain tensions emanating from differences in the business cultures of the two banks. In such cases, it is very difficult to say whether the evidence of national identity one encounters in the words and actions of those studied is an expression of personal national identities, or something elicited 
by the salient organisational context of merger. Moreover, an institution such as the Bank of Scotland has (or perhaps had) a strategic awareness of its 'Scottishness', which it cultivates and capitalises on. The agencies of the organisation, and of its members, are difficult to tease apart. To point to various kinds of organisations as agents in themselves is not to reduce individual agency to an effect of structural processes, but rather to acknowledge that it is routinely invested in and shaped by larger collectivities.

To be sure, social organisations vary in scale and scope, and are not to be confused with social structures in the sense of, for instance, class, race and gender hierarchies, large demographic patterns, or economic and legal systems. But people generally relate to and find their place within such structures through the mediation of social organisations which more directly shape their lives and mobilise interests and identities. And for most human beings, the largest and most encompassing organisation mediating their relationship to those structures is the modern state. But the key point here is that while the everyday enactment of nationalism isn't prescribed by social structure, it is framed and shaped by more immediate forms of social organization that tie people into such structures.

\section{On meaning, legitimacy and identity}

The focus on everyday nationalism is also presented as a necessary way to get at 'meaning', and what makes nations meaningful to ordinary people in their daily lives. And if, in Weberian style, we see social action as by definition meaningfully oriented, then this has to be a concomitant of the concern with agency. But why does meaning matter exactly? There are at least two answers to this question. A classic humanist answer is that we want to understand the experiences of others, to be able to identify with their view of the world, because this enriches us and expands our consciousness. In this formulation the merits of 'understanding' (Verstehen) are often counter-posed to the preoccupation with 'explanation' (Hewitson 2015: 149- 79, Little 1991: 68-87). This was a part of Weber's answer, but only part. Another very important reason for his interest in and emphasis on the importance of meaning was that social action is fundamental to matters of causation in human affairs, and we cannot account for social action if we do not know how it is meaningfully oriented. But the larger quarry was still causal explanation (Käsler 1988). And this points us back to the larger organisational contexts in which meanings are often articulated and through which social action is often amplified and focused. If we are only interested in sympathetically grasping what nations and nationalism mean for ordinary people as an end in itself that's one thing, but if this is a stage in a larger process of causal explanation, then we may ultimately be obliged to work our way back up from the micro to the macro. A social universe in which nations and nationalism are meaningful objects orienting action may not be the result of myriad small-scale acts of attributing meaning. It may be itself an emergent property of a larger social and cultural context, which can only be understood by examining the larger currents and processes of human history. This might therefore open the question of the heuristic value of a research method aimed at studying the everyday as the 'practical accomplishment of ordinary people doing ordinary things'. 
The 'evidence problem' posed here has interesting parallels with one encountered in regard to the study of power. How do we know power exists apart from when it is manifestly demonstrated by success in a contest? Where does it go, or does it exist hidden in some latent form (Hearn, 2012: 13-15)? The answer would seem to be that we reasonably attribute power to any object that routinely demonstrates such success, but that we don't expect it to be constantly in evidence. The search for everyday nationalism would seem to have a similar problematic. If people intermittently act in terms of the nation, does everyday nationalism abide only in those moments, or are these taken as evidence of an underlying and relatively constant condition-something more like Billig's banal nationalism? Is the nation itself created in these moments of expression, or do they simply evidence a nation which is constantly underlying? Systematic investigation may require taking an initial position on this basic conceptual question.

The study of 'legitimacy' is also bedevilled by a similar problem. When authority is working smoothly and unchallenged, it can be difficult to tell how it works, or if it's really even there. Do people obey because they believe, or willingly accept, out of habitual acquiescence, or out of sheer ignorance? Legitimacy is most evident in the breach, when it breaks and fails, and we can ask what it is exactly that has stopped working. Here the comparison of conceptual problems is not just formal, but substantive. Because the idea of banal nationalism at least, is related to how nations and nationalism achieve legitimacy by being naturalised, by becoming part of the 'doxa'. Does the idea of everyday nationalism share this concern with legitimacy, with how power relations within society, on up to the state, are rendered natural and acceptable, or is it a relatively more 'apolitical' concept? This is a critical question for defining what it is we are talking about here, and how it might be evidenced.

Fox and Ginderachter also suggest that the 'everyday' approach is important for understanding how national identity works. Much hinges on what we mean by 'identity'. Minimally, this term tends to cover two rather different things. On the one hand, we talk about identities as large social categories into which we place and classify people, in terms of nationality, race, ethnicity, gender, class, and endless other social taxonomies built into culture and language. On the other hand, we talk about identity as an aspect of the individual self, every person having a unique sense of who they are. More broadly, social identity is precisely about how we connect our personal identities to these larger categories, about how the categories become more or less salient according to how they relate to and explain personal experiences (see Hearn 2013). So it may be that part of what everyday nationalism provides evidence of is how this happens. It helps show us how individual selves get 'sutured' (Hall 1996: 5-6) into taxonomies of identities, and how strange, subtle and quixotic this process can be. Correspondingly, the difference between the 'everyday' focus and the 'banal' focus, may have something to do with the difference between the acts of identification made by concrete selves (sometimes unconsciously), and the social and cognitive embedding of those categories and taxonomies through social discourse. Having said this, as suggested at the end of the previous section, we shouldn't forget that this polarity of self and social category is mediated by myriad social organisational contextsfamilies, friendship networks, workplaces, associations, and so on-that help steer selves into and out of these categories. The search for everyday nationalism, which frequently uses ethnographic and microsociological methods, is framed by these specific social contexts, which put a certain spin, and 
contextual meaning, on the quotidian acts of national practice. The social researcher searching for evidence of national identity in the everyday, needs to be alert to these nuances, to the contextual specificity of the evidence they are collecting.

\section{Moving from the singular to the plural nation}

Until now we have worked with an understanding of the nation in the singular, as this is indeed a recurrent understanding in numerous studies of banal and everyday nationalism. Yet, scholars wishing to unearth the unreflexive dispositions towards the nation and/or its practical (re)enactment in the everyday should also consider whether this is really the case. It is particularly noticeable, for instance, that in Banal Nationalism Billig clearly affirms that "different factions, whether classes, religions, regions, genders or ethnicities, always struggle for the power to speak for the nation, and to present their particular voice as the voice of the national whole" (Billig, 1995: 71). Yet, despite this acknowledgment, the book conceptually relies on a nation defined in the singular. The "different classes, religions, regions, genders or ethnicities" do not produce a multivocality of national meanings, but they battle in order to be able to exclusively speak for the nation. In other words, Billig's view of a heterogeneous national audience does not translate into an open acknowledgement of the plurality of the nation (Antonsich, 2016a; Skey, 2009). Similarly, in the highly celebrated book by Edensor (Edensor, 2002), everyday nationalism offers an image of the nation that is blind to the ethnic, racial, and religious diversity which populate it. The tendency is instead to look at the material and performative reproduction of a stable and mono-cultural nation - a national mainstream which goes unchallenged. Also Fox (2017), in a recent article which largely echoes the present quest for unearthing the underground processes of nationalism, operates with the notion of a singular nation. In fact, implicit in his idea of 'repair work' after a breach has unsettled the national routine is the notion of a mainstream: the nation is brought back to its 'normality'. Yet, 'normality' is obviously far from being a politically neutral concept, as it is instead imbued with a cultural mainstream that hardens the national border to expunge people, objects and actions which are perceived to subvert that stable condition (Antonsich, 2016b). The restoration of a mainstreamed, normalized nation is thus instrumental to the reproduction of a hegemonic national group which polices the boundaries and the meanings of the nation (Hage, 2000).

This point is important when we come to reflect on the purpose of the 'evidence problem'. The risk, in fact, is to look for evidence which inadvertently contributes to essentialise the object under study. Bringing to light the underground work of banal nationalism, however illuminating it might be in terms of understanding the mechanisms of the reproduction of the nation, would also leave unchallenged the very idea of a stable, singular and state-centric nation at work in banal nationalism and, in some cases, also in everyday nationalism. More profitable, instead, would be to look for evidence which troubles the smooth reproduction of nationalism or, if we were to use Fox's (2017) terminology, to make an alternative use of 'breaches'. Rather than focusing on the 'repair work', our invitation is to fully embrace those breaches for their transformative potential. For instance, the battles to be homosexual and serve 
in the US military forces (Kier, 1998), to be a woman soldier and performing combat roles (King, 2015), to re-write school curricula so to accommodate colonial and post-colonial histories (Modood, 2007), to be Arab activists and at the same time being regarded as loyal British citizens (Nagel \& Staeheli, 2008), to perform ethnic food practices in Minnesota (Trudeau, 2006), to be Black Italians and celebrate the victory of the Azzurri without being harassed (Khouma, 2010), can all be regarded as acts of national transgressions or, better, acts which stretch the national imaginary beyond its consolidated boundaries. Rather than focusing, though, on the 'repair work' which would reproduce the banal, 'normal', mainstreamed nation, our suggestion would be to attend to the ways these acts open up the singularity of the nation and challenge the hegemony of the ethno- cultural group that sustains it. However normative this call might sound, it is actually an invitation to take the act of breaching itself as generative of plural understandings of nation. Far from a unified site, the nation is in fact also a product of everyday contestation and disagreement, an extremely dynamic and ambiguous process made of multiple, conflicting ordinary voices. Not listening to this polyphonic production would be to treat the nation as something outside history, something which does not adjust to the changing of people and times.

On a related note, we should also consider how the 'evidence problem' might also challenge something which, in Billig's understanding of banal nationalism, works as a normative assumption, namely the fact that there is nothing positive about the nation. This latter is in fact treated as a mere symbolic mechanism in the functioning of nationalism which, in turn, is never benign (Billig, 1995: 6-7). Behind every state with their 'vast armaments' (Billig, 1995: 7), there is a nation which can be used to fuel and justify the use of those armaments. The malignity of the nation is also perceived in its inherent exclusionary thrust (Billig, 2016), as it is articulated around a 'we' intrinsically opposed to 'them'. Yet, there is more to nations than a search for evidence might reveal. The nation in fact also works to motivate and sustain civic engagement (Brubaker, 2004: 121-122), social solidarity (Calhoun, 2007: 171), and economic redistribution (Johnston, Banting, Kymlicka, \& Soroka, 2010; Miller \& Ali, 2014). More recently, the adoption of affect in nationalism studies (Closs Stephens, 2016; Merriman \& Jones, 2016; Militz \& Schurr, 2016; Sumartojo, 2016; Wetherell, McCreanor, McConville, Barnes, \& le Grice, 2015) also expands on narratives of the personal, intimate, and emotional nation (Cohen, 1982; Hearn, 2007; Thompson, 2001), which go beyond a state-centric and malign register, intrinsically associated with a 'we' vs. 'them' opposition. Being open to surprise when looking for evidence (Agnew, 2006) might therefore reveal more positive sides to the nation than what banal nationalism might expect.

\section{Conclusion}

In 1995, when Billig's seminal book was published, hot nationalisms were in full swing. The Yugoslavian break-up led to bloody inter-ethnic conflicts, the Rwandan genocide left about one million people dead, and only a few years earlier the United States claimed a new world order on the ashes of the ill-fated Iraqi invasion of Kuwait. While the world was burning 'out there', quiet and peaceful - relatively speaking - was life 'in here'. The importance of Billig's argument was to show the links between these 
two worlds: the very possibility of hot nationalism - Billig argued - relies in the silent, unreflexive, daily working of banal nationalism.

Today the context within which Banal Nationalism was written has changed. Hot nationalisms are no longer 'out there', but pervade daily life 'in here'. The financial crisis, the European crisis, the migration crisis, and the terrorist crisis inform what we daily watch, hear, and, more often than not, hotly discuss. Government and public answers to all these crises are also nationally inflected. "Restore our sovereignty and democracy", "Control our own borders", "Preserve British rights and values" or "America first" are some of the current calls for a conscious and active re- nationalization of national societies in the Western world and beyond (Antonsich, 2017). In this context, one might wonder what space is left for a nation banally reproduced in the everyday life. And yet, given the continuum between banal and hot nationalism, it is legitimate to assume that even in the present conjecture the nation continues to operate unnoticed in the routine happening of social life. Thus, the 'evidence problem' is certainly a legitimate object of enquiry.

In this article we have attended to this problem, trying to explicate its different facets. In fact, it would be more accurate to talk of 'evidence problems' in the plural, because people indeed 'do' different things with the nation. In fact, following the original insight of Fox and Miller-Idriss (2008a), people not only talk about, but also talk with the nation. Accordingly, students of everyday nationhood should distinguish between when the nation is a mindful object of intention and action, when it is a discursive category consciously activated to orient action, or when it operates subliminally, as an unnoticed background in daily life. All these instances imply different types of evidence.

A second consideration relates to the tendency of everyday nationalism to see itself as a point of departure from the more traditional, historical approaches which have long characterised nationalism studies. In fact, while the latter are mainly concerned with questions of origin ('when') and nature ('what') of the nation, the former privileges questions of reproduction ('how'), context ('where'), and actors ('who'), generally adopting ethnographic rather than historical methods (Antonsich, 2015). However true this might be, we would like to caution against the possible risk of keeping macrostructural approaches separated from micro investigation of everyday life. As we have argued in this article, individual agency should be studied in relation to social organizational contexts. Any nation is not and cannot be only the product of myriad individuals attributing sense to the nation itself, but an emergent property of complexly organized behavior. Thus, joining the debate between Smith (2008) and Fox and Miller-Idriss (2008b), we would call for further empirical research which could bridge the apparent divide between 'macro' (structure) and 'micro' (individual agency) in nationalism studies (for a recent attempt in this direction see Kaufmann, 2017). This might also be relevant to understand how everyday nationalism positions itself in relation to the legitimacy question. In fact, while banal nationalism clearly shows how the mundane, unwaved flag contributes to the naturalisation of the link between nation and state, everyday nationalism is more ambiguous in this regard, avoiding dealing directly with this 'political' question.

A third and final consideration regards the question whether how we pose the 'evidence problem' helps reinforce the idea of a stable, fixed, normalized nation or points to the open, dynamic and contested 
nature of this construct. It is a question regarding the purpose of evidence, as the risk might be to essentialise the object of our study rather than critically interrogating issues of national (re)production.

While we remain very sympathetic to the endeavour of looking for evidence for the banal and everyday happening of the nation, we have also tried to reflect on the multiple theoretical and methodological facets of the evidence problem, as well as its purpose. As a great part of the Western world seems to experience today a renewed surge of nationalism, to further study its inner logics cannot be a more timely task.

\section{References}

Agnew, J. (2006). Open to surprise? Progress in Human Geography, 30(1), 1-4. Antonsich, M. (2015). Nations and nationalism. In J. Agnew, V. Mamadouh, A. Secor, \& J. Sharp (Eds.), Companion to Political Geography (pp. 297-310). Oxford: Wiley-Blackwell.

Antonsich, M. (2016a). The 'everyday'of banal nationalism - Ordinary people's views on Italy and Italian. Political Geography, 54, 32-42. doi:http://dx.doi.org/10.1016/j.polgeo.2015.07.006

Antonsich, M. (2016b). The neoliberal culturalist nation: voices from Italy. Transactions of the Institute of British Geographers, 41(4), 490-502.

Antonsich, M. (2017). The return of the nation: When neo-nationalism becomes mainstream. Retrieved from http://societyandspace.org/2017/01/31/the-return-of-the-nation-when-neo-nationalismbecomes-mainstream/

Billig, M. (1995). Banal Nationalism. Thousand Oaks, CA: Sage.

Billig, M. (2016). Nationalism, exclusion and inclusion. Identities, forthcoming, 2-6.

Brubaker, R. (2004). In the name of the nation: Reflections on nationalism and patriotism. Citizenship Studies, 8(2), 115-127.

Calhoun, C. (2007). Nations matter: citizenship, solidarity and the cosmopolitan dream London: Routledge.

Christian, J., Dowler, L., \& Cuomo, D. (2015). Fear, feminist geopolitics and the hot and banal. Political Geography, 54, 64-72.

Closs Stephens, A. (2016). The affective atmospheres of nationalism. Cultural Geographies, 23(2), 181198.

Cohen, A. P. (Ed.) (1982). Belonging. Identity and social organisation in British rural cultures. Manchester: Manchester University Press.

Edensor, T. (2002). National identity, popular culture and everyday life: Berg Oxford. 
Fox, J. E. (2017). The edges of the nation: a research agenda for uncovering the taken-for-granted foundations of everyday nationhood. Nations and Nationalism, 23(1), 26-47.

Fox, J. E., \& Miller-Idriss, C. (2008a). Everyday nationhood. Ethnicities, 8(4), 536-563. Fox, J. E., \& MillerIdriss, C. (2008b). The 'here and now' of everyday nationhood. Ethnicities, 8(4), 573-576.

Giddens, A. (1984). The constitution of society: outline of the theory of structuration. Cambridge: Polity. Hage, G. (2000). White nation: Fantasies of white supremacy in a multicultural society. London: Routledge.

Hearn, J. (2007). National identity: banal, personal and embedded. Nations and Nationalism, 13(4), 657674.

Hearn, J. (2012). Theorizing power. Basingstoke: Palgrave Macmillan.

Hearn, J. (2017). Salvage ethnography in the financial sector: The path to economic crisis in Scotland. Manchester: Manchester University Press.

Johnston, R., Banting, K., Kymlicka, W., \& Soroka, S. (2010). National identity and support for the welfare state. Canadian Journal of Political Science, 43(02), 349-377.

Jones, R., \& Merriman, P. (2009). Hot, banal and everyday nationalism: Bilingual road signs in Wales. Political Geography, 28(3), 164-173.

Kaufmann, E. (2017). Complexity and nationalism. Nations and Nationalism, 23(1), 6- 25.

Khouma, P. (2010). Noi italiani neri. Storie di ordinario razzismo. Milano: Baldini\&Castoldi.

Kier, E. (1998). Homosexuals in the US military: Open integration and combat effectiveness. International Security, 23(2), 5-39.

King, A. (2015). The female combat soldier. European Journal of International Relations, 1354066115581909.

Latour, B. (1987). Science in action: How to follow scientists and engineers through society. Cambridge, Mass.: Harvard University Press.

Merriman, P., \& Jones, R. (2016). Nations, materialities and affects. Progress in Human Geography, doi: $10.1177 / 0309132516649453$

Militz, E., \& Schurr, C. (2016). Affective nationalism: Banalities of belonging in Azerbaijan. Political Geography, 54, 54-63.

Miller, D., \& Ali, S. (2014). Testing the national identity argument. European Political Science Review, 6(02), 237-259.

Modood, T. (2007). Multiculturalism. A civic idea. Cambridge: Polity Press. 
Nagel, C. R., \& Staeheli, L. A. (2008). Integration and the negotiation of 'here' and 'there': the case of British Arab activists. Social \& Cultural Geography, 9(4), 415-430. doi:10.1080/14649360802069019

Skey, M. (2009). The national in everyday life: A critical engagement with Michael Billig's thesis of Banal Nationalism. The Sociological review, 57(2), 331-346.

Smith, A. D. (2008). The limits of everyday nationhood. Ethnicities, 8(4), 563-573.

Sumartojo, S. (2016). Commemorative atmospheres: memorial sites, collective events and the experience of national identity. Transactions of the Institute of British Geographers, 41(4), 541-553.

Thompson, A. (2001). Nations, national identities and human agency: Putting people back into nations. The Sociological review, 49(1), 18-32.

Trudeau, D. (2006). Politics of belonging in the construction of landscapes: place- making, boundarydrawing and exclusion. Cultural Geographies, 13, 421-443.

Wetherell, M., McCreanor, T., McConville, A., Barnes, H. M., \& le Grice, J. (2015). Settling space and covering the nation: Some conceptual considerations in analysing affect and discourse. Emotion, Space and Society, 16, 56-64. 